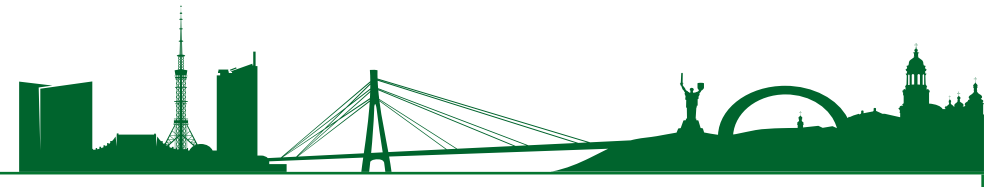

УДК 69 (477) (094.9) (045)

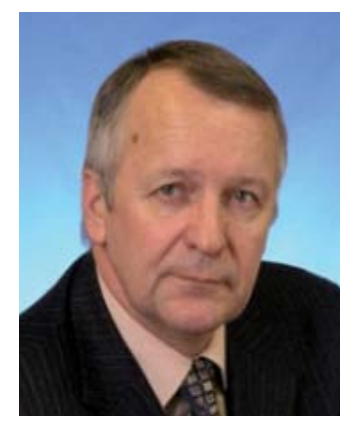

ТАРАСЮК В.Г.

Канд. технічних наук, заступник директора 3 наукової та нормативно-методичної роботи, ДП «Державний науководослідний інститут будівельних конструкцій», м. Київ, Україна, e-mail:v.tarasyuk@ndibk.gov.ua, тел.: + 38 (050) 387-97-12,

ORCID: 0000-0002-3844-1376

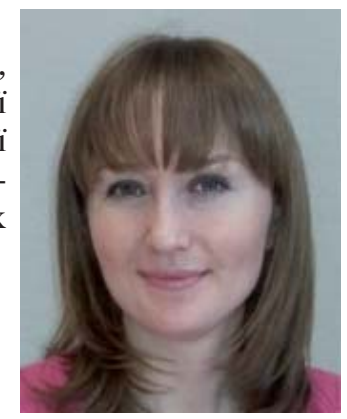

БЕЛОКОНЬ О.А.

Канд. технічних наук, завідувач відділу, ДП «Державний науково-дослідний інститут будівельних конструкцій», м. Київ, Україна, e-mail: belokon@ndibk.gov.ua, тел.: + 38 (050) 415-36-19, ORCID: 0000-0002-4722-9350

\title{
ПАРАМЕТРИЧНИЙ МЕТОД НОРМУВАННЯ У БУДІВНИЦТВІ
}

\section{АНОТАЦІЯ}

Наведено параметричний метод нормування у будівництві як один із важливих механізмів нормування у будівництві та формування безпечного середовища для життя і здоров'я людини.

Встановлено, що на сьогодні в Україні під час розроблення будівельних норм здебільшого застосовують приписувальний (або розпорядчий) метод нормування у будівництві, що не відповідає нагальним потребам на будівельному ринку та створює перешкоди для запровадження інноваційних та прогресивних технологій.

Застосування приписувального (або розпорядчого) методу нормування у будівництві не надає можливості проектувальнику в прийнятті альтернативних рішень та полягає в поелементному описі будівельного об'єкта, що в свою чергу призводить до того, що будівельні норми перетворюються в жорстку інструкцію.

Проаналізовано параметричний метод нормування у будівництві та встановлено його переваги над іншими існуючими методами.

Застосування параметричного методу нормування у будівництві забезпечить отримання нових можливостей будівельному ринку України шляхом розроблення якісних сучасних будівельних норм, що суттєво зменшуватимуть кількість необгрунтованих обов'язкових вимог при проектуванні і сприятимуть використанню інноваційних та прогресивних технологій i рішень у будівництві.

КАЮЧОВІ СЛОВА: параметричний метод нормування у будівництві, приписувальний (або розпорядчий) метод нормування у будівництві, цільовий метод нормування у будівництві, будівельні норми, підтримуючі національні стандарти.

\section{PARAMETRIC STANDARTIZATION METHOD IN CONSTRUCTION}

TARASIUK V.H. PhD, Dep. Dir. on Scientific and Normative and Methodological Work, State Enterprise "State Research Institute of Building Constructions», Kyiv, Ukraine,

e-mail: v.tarasyuk@ndibk.gov.ua,

tel.: + 38 (050) 387-97-12,

ORCID: 0000-0002-3844-1376

BELOKON O.L. PhD, Head of Department, State Enterprise «State Research Institute of Building Constructions», Kyiv, Ukraine,

e-mail: belokon@ndibk.gov.ua, tel.: + 38 (050) 415-36-19,

ORCID: 0000-0002-4722-9350

\section{ABSTRACT}

The parametric method of regulation in construction is presented as one of the important mechanisms for standardization in construction and safe environment formation for human life and health.

It has been found that now in Ukraine the construction standards are mostly developed with the application of the prescriptive (or regulatory) method of regulation in construction, which does 
not meet the urgent needs of the construction market and creates obstacles for the introduction of innovative and progressive technologies.

The application of the prescriptive (or regulatory) method of regulation in construction does not allow finding the alternative solutions by designers and envisages the element-by-element description of the construction objects, which in turn leads to the transformation of construction standards into rigid instructions.

The parametric method of regulation in construction is analyzed and its advantages over other existing methods are revealed.

The application of the parametric method of regulation in construction will provide new opportunities for the construction market of Ukraine by means of the development of high-quality modern building codes that will significantly reduce the amount of unjustified mandatory requirements in designing and will promote the use of innovative and advanced technologies and solutions in construction. KEY WORDS: parametric method of regulation in construction, prescriptive (or regulatory) method of regulation in construction, target method of regulation in construction, construction standards, supporting national standards.

\section{ВСТУП}

На сьогодні одним із важливих механізмів нормування у будівництві та формування безпечного середовища для життя і здоров'я людини $є$ здійснення діяльності з розроблення та затвердження будівельних норм для обов'язкового їх застосування у сфері будівництва, містобудування та архітектури.

Одним із прогресивних методів нормування у будівництві 6 параметричний метод нормування, що отримав широке поширення у більшості розвинутих країн.

Відомо, що параметричний метод нормування у будівництві має піввікову історію. Перші спроби застосування параметричного методу нормування у будівництві шляхом розроблення будівельних норм були зроблені на початку 1960-х років групою скандинавських країн - за участю Данії, Ісландії, Норвегії, Фінляндії та Швеції, які $з$ метою вироблення загальної політики гармонізації будівельних норм і правил сформували Скандинавський комітет з технічного регулювання.

У міру накопичення досвіду розроблення та практичного застосування будівельних норм, що розроблені на основі параметричного методу нормування у будівництві, помилки першопрохідців були враховані та виправлені.

Останнім часом параметричний метод нормування у будівництві також застосовується у стандартизації - сфері технічного регулювання, що історично базувалася виключно на приписувальному (або розпорядчому) методі нормування у будівництві. При розробленні міжнародних стандартів параметричному методу нормування у будівництві надається перевага перед приписувальним (або розпорядчим).

Таким чином, будівельні норми, що розроблені на основі параметричного методу нормування у будівництві - це ієрархічна пірамідальна структура, що складається з комплексу вимог різного рівня - від нижчого, де задаються технічні параметри об'єкта нормування, до вищого, де декларуються загальні параметри у формі абстрактних понять.

\section{ПОСТАНОВКА ПРОБАЕМИ}

Під час розроблення будівельних норм в Україні здебільшого застосовують приписувальний (або розпорядчий) метод нормування у будівництві, що не відповідає нагальним потребам на будівельному ринку та створює перешкоди для запровадження інноваційних та прогресивних технологій.

Приписувальний (або розпорядчий) метод нормування у будівництві $є$ найстарішим серед інших методів нормування, що докладно описує матеріали та методи, розміри та місце розташування конструкцій i компонентів, а також інші специфічні характеристики, що забезпечують досягнення мети нормування. В силу своєї приписувальної (або розпорядчої) природи будівельні норми, що розроблені на основі приписувального (або розпорядчого) методу нормування у будівництві, недостатньо гнучкі в області застосування альтернативних рішень, матеріалів i методів. Це значно обмежує проектувальника та можливість економії ресурсів у разі, якщо замість запропонованих матеріалів і методів можливе використання замінників, що за своїми технічними характеристиками не гірші або навіть кращі встановлених.

Тому, під час розроблення будівельних норм слід застосовувати відповідний метод нормування у будівництві, що сприятиме в подальшому забезпеченню та досягненню відповідної цілі.

META CTATTI - проаналізувати параметричний метод нормування у будівництві та встановити його переваги над іншими існуючими методами.

\section{ВИКААД ОСНОВНОГО МАТЕРІААУ}

3 метою удосконалення нормування у будівництві шляхом вивчення існуючих методів нормування у статті представлено відповідні матеріали згідно 3 [1-4].

у більшості розвинутих країн під час розроблення будівельних норм та формулювання нормативних вимог застосовується параметричний 


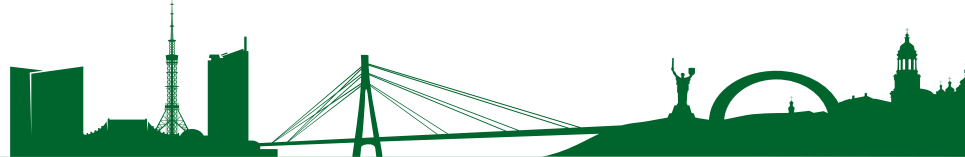

метод нормування у будівництві, що передбачає встановлення параметрів, що визначають безпеку, функціональність та якість об'єкта нормування.

В якості параметрів використовують цілі, функціональні вимоги та критерії, яким повинен відповідати об’єкт нормування. Для дотримання нормативних вимог будівельних норм передбачено два методи: прийнятних і альтернативних рішень. У такому разі проектувальнику надається можливість щодо вибору методу для дотримання нормативних вимог, що встановлені в будівельних нормах.

Так, метод прийнятних рішень передбачає застосування існуючих, як правило, приписувальних (або розпорядчих) нормативних вимог, що схвалені відповідним центральним органом виконавчої влади у сфері будівництва. Регулюючі прийнятні рішення в будівельних нормах та стандартах задають прийнятні для споживачів технічні характеристики об'єкта нормування. Застосовувані в рамках прийнятних рішень будівельні норми та стандарти випливають з параметричних вимог, котрим повинні відповідати прийнятні проектно-будівельні рішення.

Метод альтернативних рішень полягає в тому, що для забезпечення відповідності об'єкта нормування параметричним вимогам можуть бути використані інші, альтернативні технічні рішення, що відрізняються від прийнятних рішень.

Метод альтернативних рішень дозволяє проектувальникам, будівельникам і експлуатаційникам застосовувати на практиці інноваційні рішення, що не вписуються в жорсткі рамки прийнятних рішень. Причому застосування альтернативних рішень допускається тільки у разі, якщо вони забезпечують відповідний рівень безпеки, функціональності та якості об'єкта нормування не нижче показників, що встановлені у затверджених будівельних нормах і прийнятих стандартах, що застосовуються у рамках методу прийнятних рішень.

Допоміжним засобом дотримання будівельних норм, що розроблені на основі параметричного методу нормування у будівництві, є методи оцінювання відповідності, застосування яких припускає надання доказів нормативної відповідності будівельних рішень.

Також слід відзначити, що серед інших засобів дотримання будівельних норм, що розроблені на основі параметричного методу нормування у будівництві, є документальні докази (сертифікати відповідності, протоколи випробувань, експертні оцінки, рішення уповноваженого органу влади тощо), схвалені процедури, порівняння альтернативних рішень 3 прийнятними, документально зафіксовані та підтверджені факти успішного практичного застосування альтерна- тивних рішень і багато іншого. Прикладом такого засобу в Україні можна вважати свідоцтво підтвердження придатності.

На сьогодні, в Україні під час розроблення будівельних норм застосовують приписувальний (або розпорядчий) метод нормування у будівництві, що не роз'яснює ані цілей, ані функціональних вимог, ані критеріїв їх виконання.

Застосування приписувального (або розпорядчого) методу нормування у будівництві не надає можливості проектувальнику в прийнятті альтернативних рішень та полягає в поелементному описі будівельного об'єкта, що в свою чергу призводить до того, що будівельні норми перетворюються в жорстку інструкцію, що не передбачає використання нових технологій і альтернативних рішень в будівництві.

Крім того, будівельні норми можуть містити прямі посилання на стандарти, що стають також обов'язковими до застосування.

Приписувальний (або розпорядчий) метод нормування у будівництві не роз'яснює цілі нормативних вимог (наприклад, встановлена ширина проїзду становить 6 м і при цьому відсутні роз'яснення цілі, що має бути досягнуто). Функціональні вимоги, як правило, не сформульовані, функція, що повинен виконувати об'єкт нормування, сама собою мається на увазі.

Одним із найбільших недоліків будівельних норм, що розроблені на основі приписувального (або розпорядчого) методу нормування у будівництві, є їх громіздкість, що ускладнює їх перегляд та здорожчує вартість підтримки в актуальному стані. Це також ускладнює сприйняття та використання таких будівельних норм споживачами. 3 ускладненням будівельних технологій збільшується громіздкість будівельних норм, що розроблені на основі приписувального (або розпорядчого) методу нормування у будівництві, і в результаті останні значно збільшуються за обсягом та ускладнюються за змістом.

Такий ефект пояснюється тим, що будівельні норми, розроблені на основі приписувального (або розпорядчого) методу нормування у будівництві, намагаються сформувати «віртуальний макет» будівлі або споруди шляхом опису всіх аспектів його конструкції, будівництва та експлуатації від фундаменту до блискавковозахисту, від влаштування підлоги до збирання побутового сміття.

Відомо, що радянські будівельні норми і правила СНиП та СН також засновані на приписувальному (або розпорядчому) методі нормування у будівництві.

У світовій практиці застосовують ще цільовий метод нормування у будівництві, що є перехідним і містить в собі елементи приписувального (або розпорядчого) та параметричного методів.

Доречно відмітити, що цільовий метод нормування у будівництві був вперше узятий на 


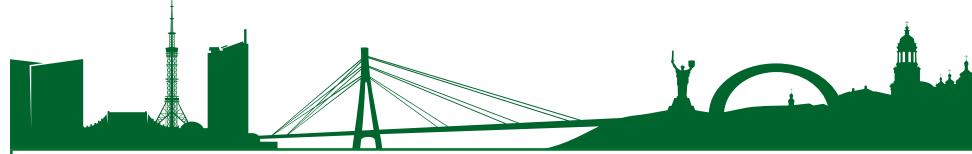

озброєння розробниками Національних кодексів Канади в середині 1990-х років, коли система нормування, що використовувалася протягом попередніх 50-ти років, почала проявляти симптоми недієздатності.

Водночас, після уважного вивчення досвіду розроблення i застосування параметричних будівельних кодексів у скандинавських країнах, Великобританії, Австралії та Новій Зеландії, канадські фахівці дійшли висновку, що негайний перехід від приписувального (або розпорядчого) методу нормування у будівництві до параметричного матиме шоковий ефект на суб'єктів системи технічного регулювання.

3 метою уникнення небажаних наслідків було прийнято рішення зробити еволюційний перехід до параметричного методу нормування у будівництві шляхом застосування концепції гібридного нормування.

Нова концепція була названа цільовою, оскільки розробники виходили з постулату про те, що всі нормативні вимоги за своєю суттю є цілями нормування різного рівня, від абстрактних, соціально значущих цілей високого рівня, до критеріїв оцінки технічних характеристик об'єктів нормування, мета яких, у свою чергу, полягає в забезпеченні досягнення соціально значущих цілей.

На виконання плану дій Уряду та з метою створення безпечного середовища для здоров'я та життедіяльності людини (в тому числі для осіб з інвалідністю та інших маломобільних груп населення) Міністерством регіонального розвитку, будівництва та житлово-комунального господарства України розроблено проект Закону України «Про внесення змін до Закону України «Про будівельні норми» (далі - законопроект), яким при формуванні обов'язкових вимог будівельних норм виходячи з особливостей об'єкта нормування пропонується застосування відповідного методу нормування у будівництві, зокрема параметричного.

Так, застосування параметричного методу нормування у будівництві забезпечить отримання нових можливостей будівельному ринку України шляхом розроблення якісних сучасних будівельних норм, що суттєво зменшуватимуть кількість необгрунтованих обов'язкових вимог при проектуванні і сприятимуть використанню інноваційних та прогресивних технологій i рішень у будівництві. Також застосування вищезазначеного методу посилить інвестиційну привабливість будівельного ринку та розвиток будівельної галузі України в цілому.

Таким чином, перевагами параметричного методу нормування у будівництві над існуючими методами є:

- встановлення параметрів (цілей, функціональних вимог, критеріїв) щодо без- пеки та якості, яким повинен відповідати об'єкт нормування;

- можливість використання проектувальниками прийнятних та альтернативних рішень у будівництві;

- роз'яснення цілей обов'язкових вимог, що мають бути досягнуті, чітка ієрархія цілей та завдань.

Також позитивним є те, що в будівельних нормах, розроблених на основі параметричного методу нормування у будівництві, відпадає необхідність відслідковувати зміни, що стосуються будівельних технологій, матеріалів і виробів та відображати зміни, що відбуваються в нормативних вимогах. Оскільки такі будівельні норми не регламентують практичне застосування будівельних технологій, матеріалів і виробів, розробникам немає потреби докладно описувати різні аспекти застосування будівельних технологій, матеріалів і виробів в об'єктах нормування.

Такий підхід значно скорочує кількість і обсяг будівельних норм, що розроблені на основі параметричного методу нормування у будівництві, що істотно спрощує та здешевлює підтримання їх в актуальному стані. Крім того, оскільки соціально значимі цілі та функціональні вимоги є фундаментальними вимогами, вони не вимагають частого перегляду та зміни, що також здешевлює вартість перегляду будівельних норм, що розроблені на основі параметричного методу нормування у будівництві.

Водночас, $\epsilon$ ряд питань, що потребують вирішення паралельно із запровадженням в Україні параметричного методу нормування у будівництві. I в першу чергу, це пов'язано iз необхідністю розроблення підтримуючих національних стандартів, що будуть забезпечувати виконання відповідних встановлених нормативних вимог у будівельних нормах, розроблених на основі параметричного методу нормування у будівництві.

Відповідно до Закону України «Про стандартизацію» замовниками послуг 3 виконання робіт 3 національної стандартизації за рахунок коштів Державного бюджету України є центральні органи виконавчої влади, а єдиним надавачем таких послуг - Національний орган стандартизації.

Aле, на жаль, на сьогодні, фінансування робіт із стандартизації будівельної галузі України не забезпечується ні Міністерством економічного розвитку та торгівлі України як центрального органу виконавчої влади, що забезпечує формування державної політики у сфері стандартизації, ні Міністерством регіонального розвитку, будівництва та житлово-комунального господарства України як центрального органу виконавчої влади, що забезпечує формування державної 
політики будівельної галузі України.

Тому питання, що пов'язані із фінансуванням робіт із стандартизації будівельної галузі України, перш за все, має бути урегульовано на рівні держави.

\section{ВИСНОВКИ}

Таким чином, параметричний метод нормування у будівництві є одним із важливих механізмів в напрямку забезпечення принципів державної політики у сфері нормування у будівництві, зокрема щодо створення безпечних умов для життя та здоров'я людини та відповідності будівельних норм вимогам законодавства, міжнародних норм та правил.

Тому, запровадження та подальше застосування в Україні під час розроблення будівельних норм параметричного методу нормування у будівництві шляхом прийняття відповідного законопроекту одночасно із прийняттям відповідних підтримуючих національних стандартів надасть можливість підвищити якість будівельних норм та зменшити кількість необгрунтованих обов'язкових вимог.

Застосування параметричного методу нормування у будівництві забезпечить замовникам можливість у виборі різних сучасних альтернативних методів досягнення поставленої мети.

\section{БІБАІОГРАФІЧНИЙ СПИСОК}

1. http://dergbud.org.ua/lectures/144-category1lecture4.html.

2. http://www.ukrgrupproekt.com.ua/index. php/ 9 - novyny/90 -vprovadzhennyaparametrichnogo-metodu-normuvannyadlya-zastosuvannya-suchasnikh-rishen-ubudivnitstvi.

3. https://economics.unian.ua/realestate/ 10148954 -minregion-proponuye-vvestiparametrichniy-metod-normuvannya-vbudivnictvi.html.

4. http://budport.com.ua/news/6174-budivelniyrinok-ukrajni-otrimaye-novi-mozhlivosti.

Стаття надійшла до редакції 03.10.2018 р. 